\title{
Active Breathing Coordinator-Mediated Radiation Therapy
}

National Cancer Institute

\section{Source}

National Cancer Institute. Active Breathing Coordinator-Mediated Radiation Therapy. NCI

Thesaurus. Code C116431.

A method for reducing the amount of radiation dose delivered to non-target tissues. The technique involves teaching the patient to hold their breath for short periods of time while the radiation is being applied. 